\title{
Censorship in an academic library
}

\author{
By Susan Podrygula
}

\section{It happened to us. Could it happen to you?}

read about the recent controversy surrounding the book Daddy's Roommate by Michael Willhoite (Alyson Wonderland, 1990) with professional interest and empathy for the librarians trying to uphold the concept of intellectual freedom in their communities. Daddy's Roommate is a children's book which portrays a young boy and his gay family. It had been the target of censors nationwide, particularly in school and public libraries and, most notably, in the "Rainbow Curriculum" in the New York City School System. A censorship challenge didn't seem like an immediate problem for our library. After all, I assumed everyone believes institutions of higher education are a place for the free exchange of ideas. Still, I wasn't totally surprised when our library director called me into his office to show me a letter asking to have Daddy's Roommate "quietly" removed from our shelves.

\section{The setting}

Some background on the institution: Minot State University (MSU) offers eleven master's degree programs as well as a full array of undergraduate programs to a student body of 3,800 . The university is located in a town with a population of 34,000 , with an additional 9,000 persons at a nearby airbase. The library moved into a brand new, state-of-the-art facility in May of 1992, tripling its size. A new library building may very well have been a contributing factor to the censorship challenge. Increased traffic, common to many new library buildings, along with a more prominent location for the Children's Collection meant increased usage. The Children's Collection offers both fiction and nonfiction materials for preschool through grade six. The primary users of the collection are students studying children's literature and education students planning school lessons. In addition to these traditional users, library staff have observed an increase in usage of the collection by "older than average" students utilizing it as a recreational reading collection for their own children.

The initial complaint about Daddy's Roommate came in the form of a letter from a local minister to the university's president. After reviewing how "ancient Greece and Rome are silent testimonies to the decaying effects of the establishment of homosexuality as normative in society," he concluded that he was sure the president would "dispense with this matter with quiet efficiency." The president forwarded the letter on to the library's director.

\section{Responding through channels}

As coordinator for collection development, I was called in to consult on the matter. I reviewed with the director the history of the book in our collection (it had been sitting on our shelves for nearly two years, checked out six times). And it had received positive reviews in School Library Journal and the Bulletin for the Center for Children's Books. A quick look at the library's "Collection Development Statement" helped us review the procedure for requests to reconsider library materials. We were confident we had done all the right things. The director then met the with university president to discuss the letter. The outcome of that discussion was that the director responded to the 
minister with a letter outlining the procedure to request the reconsideration of library materials and a copy of the form to be used for this purpose.

A couple of weeks passed without any indication of what would happen. In the meantime, the president received a second note concerning Daddy's Roommate. This time a local businessman expressed his concerns about the book, saying that it "does not represent the norm for lifestyle in Minot." We suspect, but can't confirm, that this man was a member of the church the minister serves. Again, the director sent a letter stating our policy with a copy of the form to fill out for reconsideration.

Finally the minister returned the form to request the book be formally reviewed. The cover letter stated he was "not sure that the MSU library desires the distinction of being a beachhead for the propagation of the seamy homosexual lifestyles." He answered on the form that one of his objections was the presentation of homosexuality as "just another kind of love." As far as what might be the result of using this material he stated that "parents would be infuriated that our tax dollars are purchasing this type of garbage" and a "public outcry will be unleashed, as in N.Y."

\section{Formal review of a book}

The library's "Collection Development Statement," approved by the Faculty Senate in 1984, outlined that the complaint would be reviewed by the Senate's Library Committee. The library director informed the chairperson of the committee of their task, and informed the president that a formal complaint had been received. Now the real work began in earnest. Time and time again it was reinforced that being prepared and professional paid off.

While waiting for the form to be returned, I had checked out the library's copy of Intellectual Freedom Manual (ALA, 1992). Reading and reviewing the Library Bill of Rights and its interpretations was encouraging as well as useful. A call to ALA's Office for Intellectual Freedom brought a helpful pep talk and a huge packet of information about other challenges to Daddy's Roommate. It also brought a moment of embarrassment and a sense of parochialism to me, when they remarked that they hadn't heard of any challenges to academic libraries concerning this book.

Throughout the whole process there was always the unsettling feeling of not knowing what to expect next. As university librarians, we did not expect people to challenge the contents of the collection. The ideas of intellectual and academic freedom are so taken for granted that it was almost inconceivable that we were carrying out a procedure we had never used or, for that matter, expected to use.

\section{Preparing for publicity}

Early on, the library director and I met with the director of university relations. This person serves as a spokesperson for the university and it was decided that he would handle any inquiries from the public and press. We tried to think of possible scenarios: How far would this minister take this? Would there be a public outcry like he insinuated in his complaint? Would there be a group of pickets at the library's doorstep one morning? I subsequently

. . be was "not sure that the MSU library desires the distinction of being a beachbead for the propagation of the seamy bomosexual lifestyles."

met with this person, giving him as much information as possible about the book, about our collection development policy, and about intellectual freedom in libraries. With his journalism background, he was an interested and sympathetic voice who helped us anticipate any ramifications of this problem.

The patron that had Daddy's Roommate checked out at the time the complaint was received seemed to be utilizing their full circulation period. We now had people who wanted to read the book and no copy was available. Alyson Wonderland had made an offer to donate free copies of the book to libraries that requested them. Publisher Sasha Alyson remarked, "librarians have gone to the mat for us on this one."1 A quick call to the publisher brought us a free copy via two-day mail. In addition, we borrowed a copy through interlibrary loan. Along with the library's copy, this made three copies available for the six-person Library Committee.

One issue we wrestled with was who to make aware of the complaint. There's a fine line between keeping too much in-house, perhaps seeming secretive, and going public and 
facing the possibility of things getting out of hand. The library director kept the library staff up-to-date on the process in case they were ever queried. Everyone was given instructions to refer questions or interviews to the university relations director. Certain faculty were informed on an informal basis, mainly those whose courses could be affected by the complaint (e.g., children's literature, education), and faculty that are strong supporters of the library. Of course, as more people were informed, the circle of those that knew grew, but it was kept somewhat discreet. We had some support lined up if needed, but we leaned towards being conservative and it seemed to work for us.

\section{The Library Committee completes its review}

In order to get the Library Committee and others involved in the process ready to deal with their task, we prepared an informational packet that contained the following: copies of the correspondence between the library director and the person filing the complaint, including the request for reconsideration of library materials form; a copy of the library's "Collection Policy Statement"; reviews of the book; a copy of the Library Bill of Rigbts; two interpretations of the Library Bill of Rights included in the Intellectual Freedom Manual: "Diversity in Collection Development" and "Restricted Access to Library Materials"; two chapters from the same book: "The Freedom to Read" and "Academic Libraries and Intellectual Freedom" (by Paul B. Cors); and some photocopies about the controversy surrounding Daddy's Roommate in the New York City area from the New York Newsday. These packets were distributed to the Faculty Senate Library Committee members, the University president, and the university relations director. They proved to be extremely effective, presenting an organized, business-like summary of the information involved, and they were positively received.

The Library Committee was finally convened with myself, the library director, and the university relations director present. The library director is a voting member of the committee; the university relations director and I were there to act as resource persons if needed. This was a new assignment for this committee and the members needed to examine the role intellectual freedom plays in libraries and the role academic freedom plays on campus (and in their classrooms), as well as their personal and professional opinions. By the end of the meeting, the committee passed the following statement:

"The duties of the Library Committee are to assist the library in development and use of policies concerning institutional resources. This committee reviewed the procedures of the library in procurement of this material. The library followed procedures of selection as set forth in the accepted policies. As a committee, we endorse the "Collection Policy Statement (1984)" which includes a statement of censorship. We endorse that policy which states no censorship will be exercised.

Therefore, we recommend that the reconsideration request be denied."

\section{Waiting for a reaction}

This recommendation was forwarded on to the university's president who in turn endorsed the concept of diversity in the library's collection. The president then met with the minister who filed the reconsideration form and explained the university's position. Then it was over. We waited for the aftermath. What would the consequences of the whole ordeal be?

It turned out there were no marches on the library's doorsteps or angry letters to the editor. In fact, the incident didn't seem to go beyond the campus. Perhaps we had overestimated people's interest or awareness. The local newspaper didn't even pick up the story. It never became a public controversy like past censorship incidents in Minot, which involved the public school system. Perhaps we were just lucky. Obviously going through this process makes you examine your operation and procedures. For a time we considered changing the name of the collection. We received input from some people that the name "Children's Collection" sounds like its intended audience is children (despite the fact that no one under the age of 18 can check materials out of the library). The name "Juvenile Literature Collection" was considered but never utilized, as it was really just a cosmetic change. We had more than one suggestion of restricting access to the collection. Of course, the consequences of this were politely explained and the idea rejected.

\section{Always be prepared for challenges}

It turned out the major consequence was our (Censorsbip cont. on page 83) 


\section{TECHNOLOGY FOR THE 90's AND FOR THE LIBRARIES OF TOMORROW}

\section{BLACKWELL'S PROUDLY INTRODUCES...}

\section{FOR COLLECTION DEVELOPMENT}

BLACKWELLS

Blackwell's New Titles Online database now includes Tables of Contents and Descriptive Summaries for new and forth-coming scholarly monographs.

- Browse the contents pages before placing the order

- View the publisher's title description

- Order the title electronically

- Insure a title is included on approval

- Access through the INTERNET

\section{FOR PUBLIC ACCESS CATALOGS BLACKWELLS}

Blackwell's MARC With Books ${ }^{*}$ service now offers LCMARC records enriched with Tables of Contents.

- Enhance subject access

- Improved chapter-level author access

- View contents \& summaries in your PAC before searching the shelves

- Increase interlibrary loan efficiency

FIND OUT HOW EASY AND COST EFFECTIVE IT CAN BE TO GET CONTENTS INFORMATION TO BOTH YOUR STAFF AND PATRONS TODAY!

\section{BLACKWELL \\ NORTH AMERICA, INC. \\ TECHNICAL SERVICES DIVISION}

6024 SW Jean Road, Building G, Lake Oswego, Oregon 97035. Telephone: 503-684-1140 Fax: 503-639-2481 
The graphic designs we used worked very well for brochures, bookmarks, and buttons, but were not effective for communicating our message on posters. The messages "Don't eat or drink in the library" and "Don't make noise in the library" appeared in small print at the bottom of the posters. The small print was intended to provoke interest and encourage the viewer to take a closer look. One reason that people were not drawn to read the small print may have been because of the height at which many posters had to be hung.

\section{Recommendations}

The group recommends the following actions to others who want to institute a similar campaign in their library:

1) Have a code of conduct in place before you begin the campaign. Both patrons and employees must know what is expected of them.

2) Closely examine the kinds of problems most common in your library and where they occur.

3) Devise a plan to sell your campaign. Calculate your costs and explore free sources of assistance. Check to see if a class can help.

4) Time the campaign so that things are in place at the beginning of the fall semester.

5) Be prepared to rethink your position on food, drink, and noise issues. Achieving group consensus requires some compromise.

6) Gain administrative and staff commitment to the campaign. Signs alone won't change behavior.

\section{(Indiana cont. from page 75)}

of the IU Department of Afro-American Studies. For more information call (812) 855-8547.

Although the aforementioned African American Studies collections are each housed in three different locations on the IU Bloomington campus, fundraising efforts are underway to build a new facility which could accommodate all three archives. About $\$ 2.5$ million in private donations must be raised to match state funding for the new building which will be named the Neal Marshall Black Culture Center. The new center is named after the first African American alumnus of IU, Marcellus Neal, 1895, and the first African American alumna of IU, Frances Marshall, 1919. To make a donation to the Neal Marshall Center, write to the IU Foundation, P.O. Box 500, Showalter House, Bloomington, IN 47402, or call (812) 855-8311.

\section{(Censorship cont. from page 78)}

heightened awareness of the importance of preparation for a censorship challenge. The whole process took one and a half months, but it seemed to drag out longer, perhaps prolonged by a sense of insecurity or not knowing what to expect next.

Censorship incidents can take a tremendous toll on a community, as evidenced in Cumberland County, North Carolina, where the presence of Daddy's Roommate and Heather Has Two Mommies (Alyson, 1989) on library shelves has delayed the construction of five library branches. ${ }^{2}$ As academic librarians we hadn't been lulled into complacency, but nonetheless were surprised when it happened to us. The groundwork of the past (the library's "Collection Policy Statement," and the affirmation of the concept of intellectual freedom) proved to be invaluable. Six months after we received the initial letter of complaint, we are in the midst of revising and updating our collection development statement. This experience will make us examine more closely the section on censorship and intellectual freedom, so routinely included in collection development policies, but never really expected to be used.

\section{Notes}

"Mary Jo Godwin, "Conservative Groups Continue Their Fight to Ban Daddy's Roommate," American Libraries 23 (December 1992): 968.

${ }^{2}$ Michael J. Sadowski, "Book Controversy Delays New Branches," Scbool Library Journal 39 (May 1993): 12.

(Letters cont. from page 80)

ography, medieval French philology as well as medieval French philological bibliography. Why should a university bother to hire faculty in medieval French philology, or in chemistry, or in philosophy, if its librarians can teach and perform worldly research in these and all other subjects (as McKinzie seems to claim)?

What librarians teach is (best called) BI, or (a bit less well called) documentation, or (even less well called) library skills. But to teach research simpliciter, of both kinds and in all subjects-such a suggestion is on the face of it unaware both of what such researchers $d o$ and of the meaning of the words with which we describe them and their products. $-J . M$. Perreault, bead of special collections, the University of Alabama in Huntsville 